\title{
Mechanisms Underlying Lateral GABAergic Feedback onto Rod Bipolar Cells in Rat Retina
}

\author{
Andrés E. Chávez, William N. Grimes, and Jeffrey S. Diamond \\ Synaptic Physiology Section, National Institute of Neurological Disorders and Stroke, National Institutes of Health, Bethesda, Maryland 20892-3701
}

GABAergic feedback inhibition from amacrine cells shapes visual signaling in the inner retina. Rod bipolar cells (RBCs), ON-sensitive cells that depolarize in response to light increments, receive reciprocal GABAergic feedback from A17 amacrine cells and additional GABAergic inputs from other amacrine cells located laterally in the inner plexiform layer. The circuitry and synaptic mechanisms underlying lateral GABAergic inhibition of RBCs are poorly understood. A-type and $\rho$-subunit-containing (C-type) GABA receptors $\left(\mathrm{GABA}_{\mathrm{A}} \mathrm{Rs}\right.$ and $\left.\mathrm{GABA}_{\mathrm{C}} \mathrm{Rs}\right)$ mediate both forms of inhibition, but their relative activation during synaptic transmission is unclear, and potential interactions between adjacent reciprocal and lateral synapses have not been explored. Here, we recorded from RBCs in acute slices of rat retina and isolated lateral GABAergic inhibition by pharmacologically ablating A17 amacrine cells. We found that amacrine cells providing lateral GABAergic inhibition to RBCs receive excitatory synaptic input mostly from $0 \mathrm{~N}$ bipolar cells via activation of both $\mathrm{Ca}^{2+}$-impermeable and $\mathrm{Ca}^{2+}$-permeable AMPA receptors (CP-AMPARs) but not NMDA receptors (NMDARs). Voltage-gated $\mathrm{Ca}^{2+}$ $\left(\mathrm{Ca}_{\mathrm{v}}\right)$ channels mediate the majority of $\mathrm{Ca}^{2+}$ influx that triggers $\mathrm{GABA}$ release, although CP-AMPARs contribute a small component. The intracellular $\mathrm{Ca}^{2+}$ signal contributing to transmitter release is amplified by $\mathrm{Ca}^{2+}$-induced $\mathrm{Ca}^{2+}$ release from intracellular stores via activation of ryanodine receptors. Furthermore, lateral nonreciprocal feedback is mediated primarily by $\mathrm{GABA}_{\mathrm{C}} \mathrm{Rs}$ that are activated independently from receptors mediating reciprocal feedback inhibition. These results illustrate numerous physiological differences that distinguish GABA release at reciprocal and lateral synapses, indicating complex, pathway-specific modulation of RBC signaling.

\section{Introduction}

Visual signaling in the inner retina is modulated by feedback inhibition from amacrine cells (Kolb and Nelson, 1981; MacNeil and Masland, 1998). Understanding the function of this diverse cell class is necessary to discern the signal processing performed by the inner retinal circuitry. Distinct amacrine cell subtypes make glycinergic and GABAergic inputs onto the axon and synaptic terminals of rod bipolar cells (RBCs), thereby shaping the receptive field properties of RBCs and other neurons downstream in the rod pathway (Euler and Masland, 2000; Völgyi et al., 2002; Cui et al., 2003; Eggers and Lukasiewicz, 2006a; Ivanova et al., 2006; Eggers et al., 2007; Chávez and Diamond, 2008), but the physiological properties of most amacrine cells that connect to RBCs remain poorly understood.

RBCs receive reciprocal feedback (i.e., synaptic input from amacrine cells activated directly by the same RBC) and nonreciprocal, or lateral feedback (synaptic input from amacrine cells activated by other bipolar cells) (Dowling and Boycott, 1966; Sterling and Lampson, 1986; Grünert and Martin, 1991). In the

Received Nov. 11, 2009; revised Dec. 18, 2009; accepted Dec. 24, 2009.

This work was supported by the National Institute of Neurological Disorders and Stroke Intramural Research Program. We thank members of the Diamond Laboratory for constructive discussions throughout this project.

Correspondence should be addressed to Dr. Jeffrey S. Diamond, Synaptic Physiology Section, National Institute of Neurological Disorders and Stroke, National Institutes of Health, 35 Convent Drive, Building 35, Room 3C-1000, Bethesda, MD 20892-3701. E-mail: diamondj@ninds.nih.gov.

A. E. Chávez's present address: Dominick P. Purpura Department of Neuroscience, Albert Einstein College of Medicine, Kennedy Center, Room 703, Bronx, NY 10461. E-mail: andres.chavez@einstein.yu.edu.

DOI:10.1523/JNEUROSCI.5574-09.2010

Copyright $\odot 2010$ the authors $\quad 0270-6474 / 10 / 302330-10 \$ 15.00 / 0$ rat retina, reciprocal feedback is mediated by A17 amacrine cells (Chávez et al., 2006), but the properties of the amacrine cells providing lateral GABAergic feedback to RBCs are mostly unexplored. For example, it is not known whether lateral inhibition is driven by the ON and/or OFF pathway. In addition, it is unclear whether GABA release at lateral feedback synapses is driven by $\mathrm{Ca}^{2+}$ influx through $\mathrm{Ca}_{\mathrm{v}}$ channels, release from intracellular stores, influx through glutamate receptors, or some combination of the three.

GABAergic feedback onto RBC terminals is mediated by $\mathrm{GABA}_{\mathrm{A}}$ receptors $\left(\mathrm{GABA}_{\mathrm{A}} \mathrm{Rs}\right.$ ) and $\mathrm{GABA}_{\mathrm{C}} \mathrm{Rs}$ (Fletcher et al., 1998; Koulen et al., 1998a; Lukasiewicz and Shields, 1998). These receptor subtypes are not colocalized at the same synaptic sites (Fletcher et al., 1998; Koulen et al., 1998a), suggesting that they may be activated by distinct GABAergic amacrine cell types (Palmer, 2006). At reciprocal synapses, GABA release from A17s activates $\mathrm{GABA}_{\mathrm{A}} \mathrm{Rs}$ (Singer and Diamond, 2003; Chávez et al., 2006), but enhancing GABA release can recruit $G_{A B A_{C}} R$ activation (Hartveit, 1999; Singer and Diamond, 2003; Vigh and von Gersdorff, 2005). It is unclear whether this emergent $\mathrm{GABA}_{C} \mathrm{R}$ mediated component results from receptor activation within reciprocal synapses (Fletcher et al., 1998) or spillover activation of $\mathrm{GABA}_{\mathrm{C}}$ Rs at nonreciprocal synapses.

Here, we recorded lateral GABAergic feedback IPSCs from RBCs in rat retinal slices. We found that GABAergic amacrine cells mediating lateral feedback onto $\mathrm{RBCs}$ receive excitatory input mostly from ON bipolar cells via $\mathrm{Ca}^{2+}$-permeable AMPA receptors (CP-AMPARs) and $\mathrm{Ca}^{2+}$-impermeable AMPARs and use voltage-gated $\mathrm{Na}^{+}\left(\mathrm{Na}_{\mathrm{v}}\right)$ channels to enhance input-output 
coupling. GABA release from these amacrine cells is triggered by $\mathrm{Ca}^{2+}$ influx through both $\mathrm{Ca}_{\mathrm{v}}$ channels and CP-AMPARs and is enhanced by ryanodine receptor (RyR)-mediated $\mathrm{Ca}^{2+}$-induced $\mathrm{Ca}^{2+}$ release (CICR). Lateral inhibitory synapses activate primarily $\mathrm{GABA}_{\mathrm{C}}$ Rs independently of those $\mathrm{GABA}_{\mathrm{C}}$ Rs activated by reciprocal GABA release from A17s, suggesting that reciprocal and lateral inputs target distinct postsynaptic $\mathrm{GABA}_{\mathrm{C}} \mathrm{R}$ populations on RBC terminals. These results demonstrate that fundamental physiological differences distinguish reciprocal and lateral GABAergic feedback inhibition to RBCs and suggest that these differences likely underlie the distinct roles they play in the rod pathway.

\section{Materials and Methods}

Rat retinal slices (210 $\mu \mathrm{m}$ thick) were prepared from Sprague Dawley rats (postnatal days 17-24) using previously described methods (Chávez et al., 2006; Chávez and Diamond, 2008). Briefly, retinas were isolated and sliced in standard artificial CSF (ACSF) continuously bubbled with $95 \%$ $\mathrm{O}_{2} / 5 \% \mathrm{CO}_{2}$ and containing the following (in $\mathrm{mm}$ ): $119 \mathrm{NaCl}, 26$ $\mathrm{NaHCO}_{3}, 1.25 \mathrm{Na}_{2} \mathrm{HPO}_{4}, 2.5 \mathrm{KCl}, 2.5 \mathrm{CaCl}_{2}, 1.5 \mathrm{MgSO}_{4}, 10$ glucose, 2 $\mathrm{Na}^{+}$-pyruvate, and $4 \mathrm{Na}^{+}$-lactate. Infrared-differential interference contrast video microscopy was used to target RBCs with the patch electrode. RBCs were first identified by their goblet-shaped somata located in the inner nuclear layer, directly adjacent to the outer plexiform layer (OPL), and were further revealed by fluorescent visualization, using internal solution that included Alexa 488 hydrazide ( $50 \mu \mathrm{M}$ ) (for details, see Chávez and Diamond, 2008).

Once in the microscope recording chamber, retinal slices were continuously superfused with ACSF at a rate of $1-2 \mathrm{ml} / \mathrm{min}$. Patch electrodes (8-11 M $\Omega$ ) contained the following (in $\mathrm{mM}$ ): 100 Cs-methanesulfonate, 20 TEA (tetraethylammonium)-Cl, 10 HEPES, 1.5 BAPTA, $10 \mathrm{Na}-$ phosphocreatine, $4 \mathrm{Mg}$-ATP, $0.4 \mathrm{Na}-\mathrm{GTP}, 10$ glutamic acid, pH 7.4. RBCs generally exhibited high input resistance ( $\geq 1 \mathrm{G} \Omega$ ) (Singer and Diamond, 2003; Chávez and Diamond, 2008). All experiments, except where noted, were performed at room temperature using ACSF that was supplemented with strychnine ( $3 \mu \mathrm{M})$, to block glycinergic feedback (Cui et al., 2003; Chávez and Diamond, 2008), and 5,7-dihydroxytryptamine (DHT) $(50 \mu \mathrm{M})$, a neurotoxic serotonin analog that ablates A17 amacrine cells and eliminates GABAergic reciprocal feedback (Dong and Hare, 2003; Chávez et al., 2006). The effects of exogenous application of pharmacological reagents were analyzed as previously described (Chávez and Diamond, 2008). All drugs were obtained from Sigma-Aldrich and Tocris Bioscience, except TTX (Alomone Labs), Alexa 488 (Invitrogen), and 1-(4-aminophenyl)-3-methylcarbamyl-4-methyl-3,4-dihydro-7,8-methylenedioxy-5H-2,3-benzodiazepine [GYKI 53655 (GYKI)] (a gift from Dr. John Isaac, Bethesda, MD).

Unless otherwise indicated, RBCs were voltage clamped at $0 \mathrm{mV}$ (the reversal potential for excitatory inputs) and puff application of L-glutamate ( $50 \mu \mathrm{M} ; 25 \mathrm{~ms} ; 1$ bar) in the innermost part of the inner plexiform layer (IPL) was used to elicit synaptic release from amacrine cells onto RBCs. In addition, (RS)- $\alpha$-cyclopropyl-4-phosphonophenylglyicne (CPPG) $(600 \mu \mathrm{M} ; 300 \mathrm{~ms} ; 1.5$ bar) or kainic acid (kainate) $(100 \mu \mathrm{M}$; $350-400 \mathrm{~ms} ; 1.5$ bar $)$ was puffed into the OPL $(\sim 80-100 \mu \mathrm{m}$ laterally from the recorded RBC) to activate ON and OFF bipolar cells, respectively (Chávez and Diamond, 2008). In these experiments, a group III mGluR agonist (L-AP-4) $(10 \mu \mathrm{M})$ was included in the ACSF. All puffed agents were applied using a Picospritzer II (General Valve) connected to a patch pipette (resistance, $\sim 8-10 \mathrm{M} \Omega$ ). The puffing solution was similar to control ACSF but also contained the stimulating agent (e.g., glutamate) and was pH-buffered with HEPES (10 mM). Puff application of HEPES-buffered ACSF did not evoke detectable responses in RBCs (data not shown). To measure the spatial extent of lateral GABAergic inhibition to RBCs, the glutamate-containing pipette was moved laterally in the IPL as previously described (Chávez and Diamond, 2008). Briefly, three responses were recorded at various positions within the IPL; to control for rundown after each series, the pipette was returned to $0 \mu \mathrm{m}$ and three additional responses were averaged and compared with the initial responses obtained at the beginning of the experiment. Cells ex- hibiting significant change ( $\geq 10 \%$ ) in the $0 \mu \mathrm{m}$ response were discarded from the analysis. Peak responses at each position were normalized to that recorded at $0 \mu \mathrm{m}$ in control solution and plotted as a function of distance from the RBC terminal (see Fig. 1).

GABAergic feedback IPSCs were elicited at 14-20 s intervals, filtered at $2 \mathrm{kHz}$, and sampled at $10 \mathrm{kHz}$ by an ITC-18 analog-to-digital board (InstruTECH) controlled by software written in Igor Pro (Wavemetrics). Glutamate-evoked IPSC amplitudes were measured as the difference between the response peak and the baseline preceding stimulation, whereas reciprocal feedback IPSCs were evoked by a $50 \mathrm{mV}$ depolarizing step in the RBC (vIPSC) (see Fig. 6) and the peak response was measured as previously described (Chávez et al., 2006). The slow and sustained GABA $_{C}$ R-mediated IPSC component (see Fig. 6) was measured by averaging the last $10-15 \mathrm{~ms}$ of the current response. Unless otherwise indicated, statistical comparisons were made with a paired, two-tailed Student's $t$ test (Igor Pro), and significance was concluded when $p<0.05$. Within the figures, asterisks indicate the following: ${ }^{\star} p<0.05,{ }^{\star *} p<0.01$, and ${ }^{* * *} p<0.001$, and the number of experiments $(n)$ is indicated in parentheses. Data are presented as mean $\pm \mathrm{SD}$, and illustrated traces are averages of 3-20 responses.

\section{Results}

\section{Lateral GABAergic inputs require $\mathrm{Na}_{\mathrm{v}}$ channels}

Many amacrine cells use $\mathrm{Na}_{\mathrm{v}}$ channel-mediated action potentials to enhance signaling within their dendrites (Cook and Werblin, 1994; Cook and McReynolds, 1998; Shields and Lukasiewicz, 2003). A17 amacrine cells supply reciprocal feedback independently of $\mathrm{Na}_{\mathrm{v}}$ channels (Chávez et al., 2006), but longer-distance signaling through the large $(\geq 500 \mu \mathrm{m})$ (Nelson and Kolb, 1985; Raviola and Dacheux, 1987) A17 dendritic arbor could employ action potentials (Bloomfield, 1992), enabling A17s to mediate both reciprocal and lateral inhibition. To test this possibility, we measured the spatial extent of GABAergic feedback by stimulating amacrine cells directly with brief puffs of exogenous glutamate ( $50 \mu \mathrm{M} ; 25 \mathrm{~ms})$ delivered in the IPL at different distances laterally from the voltage-clamped $\mathrm{RBC}\left(V_{\text {hold }}=0 \mathrm{mV}\right.$ ) (Chávez and Diamond, 2008). With glycinergic inhibition blocked by strychnine $(3 \mu \mathrm{M})$ in the bath solution, this stimulation protocol elicited an outward, GABAergic IPSC in the RBC (Fig. 1) (Chávez et al., 2006).

If A17s mediate both reciprocal and lateral inhibition, then specific ablation of A17s by DHT, a toxic serotonin analog (Dong and Hare, 2003; Chávez et al., 2006; Grimes et al., 2009), should decrease feedback IPSCs across the entire range of distances tested. Contrary to this prediction, bath application of DHT (50 $\mu \mathrm{M}$ for $10 \mathrm{~min}$ ) reduced glutamate-evoked feedback IPSCs only when the puff pipette was positioned directly adjacent to the synaptic terminals of the recorded RBC (to $51 \pm 9 \%$ of control response at $0 \mu \mathrm{m} ; p=0.01276 ; n=6$ ) (Fig. $1 A, C$ ) but did not significantly affect responses evoked from farther away (for 30, 50,80 , and $140 \mu \mathrm{m}$, values of $p$ are $0.07558,0.15217,0.13210$, and 0.10404 , respectively) (Fig. $1 A, C$ ). The DHT-resistant component of feedback IPSCs was abolished by subsequent application of the $\mathrm{Na}_{\mathrm{v}}$ channel blocker TTX $(0.5 \mu \mathrm{M})$ (Fig. $\left.1 \mathrm{~A}, \mathrm{C}\right)$, indicating that DHT-insensitive (non-A17) amacrine cells use $\mathrm{Na}_{\mathrm{v}}$ channeldependent signaling to drive inhibition of RBCs (Bloomfield and Xin, 2000; Shields and Lukasiewicz, 2003; Chávez et al., 2006). These results also suggest that DHT-sensitive A17 amacrine cells make only localized reciprocal synapses onto RBC terminals. Similar results were obtained when the order of the drug application was reversed: TTX blocked feedback IPSCs evoked at distances $>30 \mu \mathrm{m}$ (to $7 \pm 4$ of control response at $80 \mu \mathrm{m} ; p=$ $0.00007 ; n=6$ ) (Fig. $1 B, D)$ ( $p$ values for 110 and $140 \mu \mathrm{m}$ are 0.00245 and 0.00396 , respectively); the local TTX-insensitive component $(57 \pm 6 \%$ of control response at $0 \mu \mathrm{m})$ reflected 
GABA release from A17 cells, as it was abolished by DHT (to $3 \pm 1 \%$ of TTX response; $p=0.00001 ; n=6$ ) (Fig. $1 B, D)$. Moreover, the components remaining in DHT (Fig. 1C) and TTX (Fig. 1D), when added together, closely approximated control responses at all puff distances (Fig. $1 E$ ), indicating that the two drugs acted on independent elements contributing to GABAergic feedback. Together, these results indicate that, in rat retina, RBCs receive local $\mathrm{Na}_{\mathrm{v}}$ channel-independent feedback from A17 amacrine cells, and lateral, $\mathrm{Na}_{\mathrm{v}}$ channel-dependent feedback from other GABAergic amacrine cells. To isolate the lateral component of the glutamate-evoked IPSCs, all subsequent experiments were performed in the presence of DHT ( $50 \mu \mathrm{M})$.

\section{$\mathrm{GABA}_{\mathrm{C}}$ Rs mediate the majority of lateral GABAergic input}

GABAergic feedback IPSCs recorded from RBCs comprise both $\mathrm{GABA}_{\mathrm{A}}$ - and $\mathrm{GABA}_{\mathrm{C}} \mathrm{R}$ mediated components (Lukasiewicz and Shields, 1998; Hartveit, 1999; Singer and Diamond, 2003; Vigh and von Gersdorff, 2005; Chávez et al., 2006; Eggers and Lukasiewicz, 2006a,b), but the relative contribution of the two receptor types at reciprocal versus lateral inputs remains unclear. Here, lateral feedback IPSCs were strongly reduced by 1,2,5,6-tetrahydropyridin-4-ylmethylphosphonic acid (TPMPA) (50 $\mu \mathrm{M}$; to $17 \pm 3 \%$ of control response; $n=7 ; p=$ 0.00004) (Fig. $1 F$ ), a specific GABA $_{C}$ R antagonist. The small remaining feedback IPSC was eliminated by the $\mathrm{GABA}_{\mathrm{A}} \mathrm{R}$ antagonist, 6-imino-3-(4-methoxyphenyl)-1(6H)-pyridazinebutanoic acid hydrobromide (SR95531) $(10 \mu \mathrm{M}$; to $1.1 \pm 1.0 \%$ of control; $n=7 ; p=0.00002$ ) (Fig. $1 F$ ). $\mathrm{GABA}_{\mathrm{B}} \mathrm{Rs}$ did not contribute because the $\mathrm{GABA}_{\mathrm{B}} \mathrm{R}$ antagonist CGP54266 (3 $\left.\mu \mathrm{M}\right)$ exerted no effect on nonreciprocal IPSCs $(98 \pm 2 \%$ of control IPSC; $n=4 ; p=$ 0.16) (Fig. 1F) (Koulen et al., 1998b). Furthermore, the complete suppression of feedback responses by ionotropic GABA receptor antagonists indicates that IPSCs were not contaminated by glutamate transporter currents (Veruki et al., 2006). Together, this result indicates that lateral GABAergic feedback is primarily mediated by $\mathrm{GABA}_{\mathrm{C}} \mathrm{Rs}$; this conclusion is consistent with results from light-evoked lateral inhibition recorded from RBCs in mouse (Eggers and Lukasiewicz, 2006a,b).

\section{Presynaptic GABAergic amacrine}

\section{cells express AMPA and possibly kainate receptors}

Amacrine cells receive glutamatergic inputs from bipolar cells and express various subtypes of glutamate receptors (Dixon and Copenhagen, 1992; Euler et al., 1996; Dumitrescu et al., 2006). GABAergic A17 amacrine cells receive excitatory input via CPAMPARs (Chávez et al., 2006), but glycinergic amacrine cells that contact RBCs are driven by NMDA and $\mathrm{Ca}^{2+}$-impermeable AMPARs (Chávez and Diamond, 2008). To identify which gluCGP, CGP54266.
B
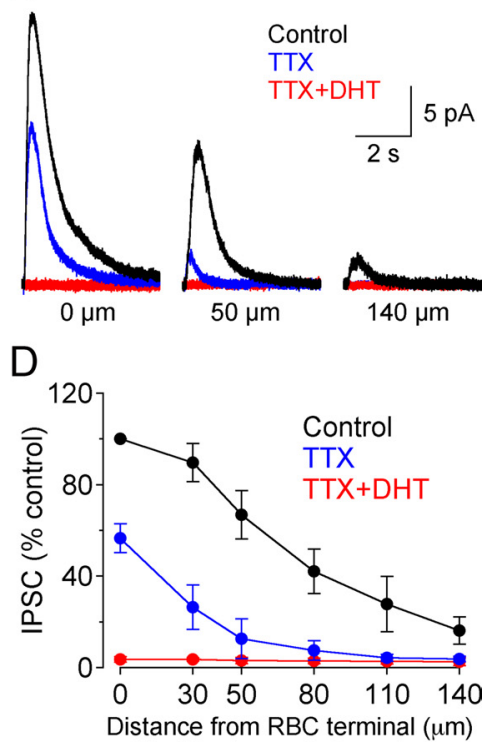

$\mathrm{F}$

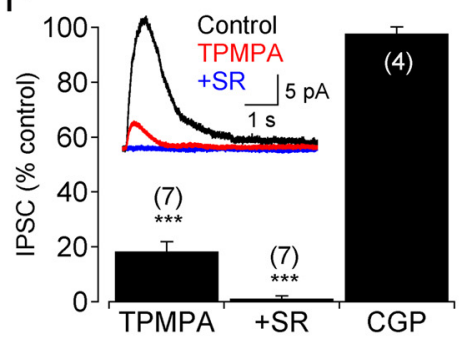

Figure 1. Spatial profile of reciprocal and lateral feedback inhibition to $\mathrm{RBC}$. $A, G A B A$ ergic IPSCs evoked by glutamate puffed at mental distances from patched $\mathrm{RBC}\left(V_{\text {hold }}=0 \mathrm{mV}\right)$ were locally sensitive to DHT $(50 \mu \mathrm{m})$ with the remaining component the presence of strychnine (3 $\mu \mathrm{m}$ ) to block lateral inhibition from GlyRs (Chávez and Diamond, 2008). ${ }^{* * *} p<0.001$. SR, SR95531

tamate receptors are expressed by GABAergic amacrine cells providing nonreciprocal inhibition to RBCs, the effects of receptor antagonists were tested on glutamate-evoked feedback IPSCs recorded in RBCs. Glutamate-evoked IPSCs were slightly, albeit insignificantly, affected by the NMDAR antagonist 3-(2carboxypiperazine-4-yl)propyl-1-phosphonic acid (CPP) (10 $\mu \mathrm{M}$; to $96 \pm 5 \%$ of control; $n=11 ; p=0.056$ ) (Fig. $2 A, D)$ but were reduced significantly by the specific AMPAR antagonist GYKI ( $50 \mu \mathrm{M}$; to $45 \pm 16 \%$ of control; $n=6$; $p=0.0017$ ) (Fig. $2 B, D)$ and eliminated completely by subsequent application of the AMPAR/kainate receptor (KAR) antagonist 2,3-dihydroxy6-nitro-7-sulfamoyl-benzo $(f)$ quinoxaline (NBQX) ( $25 \mu \mathrm{M}$; to $1 \pm 1 \%$ of control; $n=6 ; p=0.00044$ compared with GYKI alone) (Fig. 2B,D). The difference in GYKI and NBQX effects suggests that both AMPARs and KARs can mediate input to GABAergic amacrine cells. Philanthotoxin 433 (PhTx) $(1 \mu \mathrm{M})$, a CP-AMPAR antagonist, also partially blocked feedback IPSCs (to $52 \pm 10 \%$ of control; $n=12 ; p=0.00002$ ) (Fig. $2 C, D$ ). When GYKI was then added in the continued presence of PhTx, the IPSC was reduced further (to $25 \pm 7 \%$ of control; $n=6 ; p=$ 

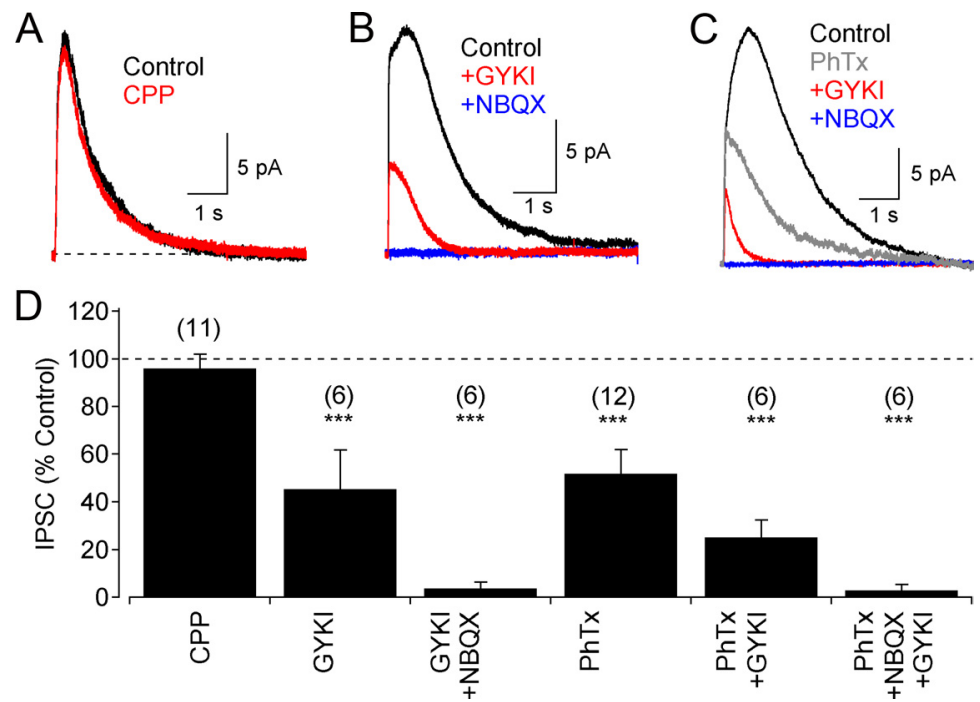

Figure 2. Non-NMDARs mediate excitatory inputs to lateral GABAergic amacrine cells. $A$, Lateral GABAergic feedback IPSCS were insensitive to the NMDAR antagonist, $C P P(10 \mu \mathrm{M}) . \boldsymbol{B}$, The responses were partially reduced by application of the AMPAR antagonist, GYKI $(50 \mu \mathrm{M})$, and eliminated by coapplication with NBQX (25 $\mu \mathrm{M})$. C, The (P-AMPAR antagonist, PhTx $(1 \mu \mathrm{M})$, partially reduced feedback IPSCs as did GYKI; the remaining response was eliminated by additional application of NBQX (25 $\mu \mathrm{M})$. $D$, Summarized drug effects (mean \pm SD) on lateral GABAergic feedback IPSCS. All experiments were conducted in the presence of strychnine $(3 \mu \mathrm{m})$ and DHT $(50 \mu \mathrm{M}) .{ }^{* * *} p<0.001$.

0.00062, $p=0.00029$ compared with PhTx alone) (Fig. 2C,D), leaving a small component that was eliminated by subsequent application of NBQX (25 $\mu \mathrm{M})$ (Fig. 2C,D). Together, these results indicate that a mixture of $\mathrm{Ca}^{2+}$-permeable and $\mathrm{Ca}^{2+}$-impermeable AMPARs primarily mediate the excitatory activation of GABAergic amacrine cells, with a small, but significant, contribution from KARs.

\section{Lateral GABAergic feedback onto RBCs is driven mostly by the ON pathway}

Exogenous agonist application (Fig. 2) may activate extrasynaptic receptors that do not normally participate in synaptic transmission. To determine which glutamate receptors mediate synaptic activation of GABAergic amacrine cells, feedback IPSCs were elicited by stimulating bipolar cell dendrites in the OPL (Fig. 3). ON or OFF bipolar cells were stimulated independently by puffing either the mGluR antagonist CPPG (Nawy, 2004) or the AMPAR/ KAR agonist kainate (DeVries, 2000) in the OPL, respectively, $\geq 80 \mu \mathrm{m}$ laterally from the $\mathrm{RBC}$ recording (Chávez and Diamond, 2008). This method stimulates synaptic circuitry in a way that is closely analogous to the light stimulation of the $\mathrm{ON}$ and OFF pathways (Kalbaugh et al., 2009). Both CPPG and kainate elicited feedback IPSCs in RBCs that were strongly reduced by the $\mathrm{GABA}_{\mathrm{C}} \mathrm{R}$ antagonist TPMPA (50 $\mu \mathrm{M}$; CPPG response: to $15 \pm$ $3 \%$ of control, $n=6, p=0.0089$; kainate response: to $9 \pm 3 \%$ of control, $n=6, p=0.0052$ ) (Fig. $3 A, B, G$ ). Subsequent application of the $\mathrm{GABA}_{\mathrm{A}} \mathrm{R}$ antagonist SR95531 $(10 \mu \mathrm{M})$ eliminated the remainder of both the CPPG- and kainate-evoked IPSCs (CPPG response: to $3 \pm 1 \%$ of control, $n=6, p=0.00091$ compared with TPMPA alone; kainate response: to $3 \pm 1 \%$ of control, $n=$ $6, p=0.00303$ compared with TPMPA alone) (Fig. $3 A, B, G$ ). Application of TTX $(0.5 \mu \mathrm{M})$, which does not directly affect transmitter release from most bipolar cells (Ichinose et al., 2005; Chávez et al., 2006) but abolishes lateral feedback transmission onto RBCs (Fig. 1), also eliminated both responses (CPPG: to $6 \pm$ $6 \%$ of control, $n=7, p=0.00001$; kainate: to $6 \pm 4 \%$ of control, $n=5, p=0.00014$ ) (Fig. $3 C, D, G$ ), confirming that both $\mathrm{ON}$ and/or OFF-responding GABAergic amacrine cells providing lateral feedback rely heavily on $\mathrm{Na}_{\mathrm{v}}$-dependent signaling.

As observed with glutamate stimulation, CPPG- and kainate-evoked IPSCs were not significantly affected by the NMDAR antagonist CPP $(10 \mu \mathrm{M}$; CPPG: to $97 \pm 4 \%$ of control, $n=7, p=0.082$; kainate: to $94 \pm 7 \%$ of control, $n=6, p=$ 0.074) (Fig. 3E-G), but both were strongly reduced by application of the CP-AMPAR antagonist PhTx ( $1 \mu \mathrm{M}$; CPPG: to $24 \pm$ $13 \%$ of control, $n=7, p=0.00095$; kainate: to $43 \pm 12 \%$ of control, $n=6, p=$ 0.00024 ) (Fig. $3 E-G$ ). In both cases, the IPSC remaining in PhTx was abolished by NBQX ( $25 \mu \mathrm{M}$; CPPG: to $3 \pm 3 \%$ of control, $n=7, p=0.00645$ compared with PhTx; kainate: to $4 \pm 3 \%$ of control, $n=$ $6, p=0.00099$ compared with PhTx) (Fig. $3 E-G)$. These results indicate that synaptic inputs to GABAergic amacrine cells are mediated primarily by CP-AMPARs, whereas $\mathrm{Ca}^{2+}$-impermeable AMPARs and/or KARs may be located extrasynaptically in amacrine cell membranes, as they are activated more strongly by exogenous glutamate (Fig. 2) than by synaptic glutamate release from ON and OFF bipolar cells.

Although GABAergic IPSCs could be elicited by either CPPG or kainate (Fig. 3), CPPG was a more effective stimulus (Fig. 4). CPPG elicited IPSCs in every (24 of 24) cell tested, whereas kainate elicited IPSCs in only 40\% (16 of 40) of RBCs tested (Fig. $4 A$ ). Even in those cells that did respond to kainate, IPSC amplitudes (7.4 $\pm 1.8 \mathrm{pA}$; range, $4-11 \mathrm{pA} ; n=16)$ were smaller than those elicited in different cells by CPPG $(10.6 \pm 4.3 \mathrm{pA}$; range, $4-23 \mathrm{pA} ; n=24 ; p=0.0093$, unpaired $t$ test) (Fig. $4 A$ ). To confirm the efficacy of kainate in a subset of nonresponsive cells $(n=18)$, the puffer pipette was moved to the IPL, where kainate could stimulate amacrine cells directly, and robust IPSCs were detected (Fig. 4 B, C). Furthermore, in nonresponsive cells, IPSCs were not detected even when the driving force on the GABAR chloride conductance was greatly increased (Fig. $4 B, C$ ), suggesting that the lack of response was not attributable to RBC insensitivity. These results indicate that RBCs receive most of their nonreciprocal GABAergic inhibition from amacrine cells activated by $\mathrm{ON}$ bipolar cells.

\section{Multiple $\mathrm{Ca}^{2+}$ sources trigger lateral GABAergic feedback} Although calcium influx through CP-AMPARs at the A17-RBC reciprocal synapse is sufficient to trigger GABA release, it seemed unlikely that the prominent CP-AMPAR-mediated synaptic input to lateral GABAergic amacrine cells (Figs. 2, 3) could do the same, because the lateral sites of excitatory input are not colocalized with the GABAergic synapses onto RBCs. Consistent with this expectation, the strong reduction of lateral feedback IPSCs by TTX (Figs. 1, 3) portends a prominent role for membrane depolarization-dependent release mechanisms (i.e., $\mathrm{Ca}_{\mathrm{v}}$ channels). Accordingly, bath application of cadmium $\left(\mathrm{Cd}^{2+}\right)(200$ $\mu \mathrm{M})$, a broad-spectrum blocker of $\mathrm{Ca}_{\mathrm{v}}$ channels, strongly but incompletely reduced glutamate-evoked IPSCs (to $13 \pm 4 \%$ of control response; $p=0.0020$ ) (Fig. $5 A, B)$. The remaining $\mathrm{Cd}^{2+}$. insensitive IPSC component was eliminated by $\mathrm{PhTx}$ (to $3 \pm 2 \%$ 
of control; $n=6 ; p=0.00228$ compared with $\mathrm{Cd}^{2+}$ alone) (Fig. $5 A, B)$, indicating that CP-AMPARs can contribute $\mathrm{Ca}^{2+}$ influx to trigger GABA release independently of $\mathrm{Ca}_{\mathrm{v}}$ channels. Feedback IPSCs were also eliminated when $\mathrm{Ca}^{2+}$ was removed from the bath (Fig. 5B), confirming that nonreciprocal GABA release is an entirely $\mathrm{Ca}^{2+}$-dependent process and that both $\mathrm{Ca}_{\mathrm{v}}$ channels and $\mathrm{Ca}^{2+}$-permeable AMPARs can provide the $\mathrm{Ca}^{2+}$ influx that is required to trigger transmitter release.

Most $\mathrm{Ca}_{\mathrm{v}}$ channel subtypes have been shown to be expressed in the IPL (Kamphuis and Hendriksen, 1998; Xu et al., 2002), and, specifically, both $\mathrm{N}$ - and L-type $\mathrm{Ca}_{\mathrm{v}}$ channels have been shown to mediate transmitter release from certain amacrine cells (Gleason et al., 1994; Habermann et al., 2003; Bieda and Copenhagen, 2004; Vigh and Lasater, 2004; Chávez and Diamond, 2008; Grimes et al., 2009). To explore which $\mathrm{Ca}_{\mathrm{v}}$ channel subtypes contribute to nonreciprocal GABA release, $\mathrm{Ca}^{2+}$-permeable AMPARs were blocked with $1 \mu \mathrm{M}$ PhTx and the effects of various $\mathrm{Ca}_{\mathrm{v}}$ channel antagonists on glutamate-evoked IPSCs were tested. Independent application of $\omega$-conotoxin GVIA (10 nM) or isradipine $(10 \mu \mathrm{M})$, the $\mathrm{N}$ - and the L-type $\mathrm{Ca}_{\mathrm{v}}$ channel antagonist, respectively, exerted large effects on feedback IPSC amplitudes (Fig. 5D), but their combined application did not suppress feedback IPSCs completely (to $19 \pm 5 \%$ of control; $n=5 ; p=0.0013$ ) (Fig. $5 C, D$ ), suggesting that other $\mathrm{Ca}_{\mathrm{v}}$ channels also may play a role in triggering GABA release. Accordingly, feedback IPSCs also were reduced by T- (mibefradil; $10 \mu \mathrm{M}$ ), P/Q- (agatoxin IVA; 200 $\mathrm{nM}$ ), and T/R-type $\left(\mathrm{Ni}^{2+} ; 100 \mu \mathrm{M}\right) \mathrm{Ca}_{\mathrm{v}}$ channel antagonists (Fig. $5 D)$. Given the nonlinear relationship between $\mathrm{Ca}^{2+}$ influx and transmitter release (Dodge and Rahamimoff, 1967) and the lack of highly specific $\mathrm{Ca}_{\mathrm{v}}$ channel antagonists, the results presented here imply that multiple $\mathrm{Ca}_{\mathrm{v}}$ channel subtypes may act cooperatively to facilitate transmitter release from amacrine cells (Bieda and Copenhagen, 2004; Chávez and Diamond, 2008).

CICR from intracellular stores contributes to $\mathrm{Ca}^{2+}$ signaling and transmitter release from amacrine cells (Gleason et al., 1994; Vigh and Lasater, 2003; Warrier et al., 2005; Chávez et al., 2006; Chávez and Diamond, 2008; Grimes et al., 2009). Here, depletion of endoplasmic reticulum $\mathrm{Ca}^{2+}$ stores with thapsigargin $(1 \mu \mathrm{M})$ reduced lateral feedback IPSCs (to $51 \pm 11 \%$ of control; $n=7$; $p=0.0055)$ (Fig. $5 F$ ), indicating a role for CICR at nonreciprocal synapses. In GABAergic amacrine cells, CICR has been shown to be mediated by RyRs and/or inositol-1,4,5-trisphosphate receptors ( $\mathrm{IP}_{3} \mathrm{Rs}$ ) (Vigh and Lasater, 2003; Warrier et al., 2005; Chávez et al., 2006). When RyRs were blocked with ruthenium red (RR) $(40 \mu \mathrm{M})$, lateral feedback IPSCs were significantly reduced (to $70 \pm 8 \%$ of control; $n=6 ; p=0.0056$ ) (Fig. $5 E, F)$. In contrast, when $\mathrm{IP}_{3} \mathrm{Rs}$ were blocked with either 2-APB $(50 \mu \mathrm{M})$ or xestospongin $\mathrm{C}(\mathrm{XeC})$ ( $3 \mu \mathrm{M})$, IPSCs were unaffected (2-APB: to $94 \pm 5 \%$ of control, $n=6, p=0.050$; XeC: to $93 \pm 9 \%$ of control, $n=4, p=0.27$ ) (Fig. $5 F$ ), suggesting that RyRs but not $\mathrm{IP}_{3}$ Rs trigger CICR to amplify intracellular $\mathrm{Ca}^{2+}$ signals at nonreciprocal synapses and enhance GABA release. Consistent with this conclusion, puff application of the RyR agonist caffeine (15 mM) evoked IPSCs that were eliminated by GABAR antagonists (to $2 \pm 1 \%$ of control; $n=4$; $p=0.016$ ) (Fig. $5 F$ ) or strongly reduced by RR (to $13 \pm 4 \%$ of control; $n=5 ; p=$ 0.00009 ) (Fig. 5F). Together, these results indicate that $\mathrm{Ca}_{\mathrm{v}}$ channels, CP-AMPARs, L-AP-4 (10 $\mu \mathrm{m})$.
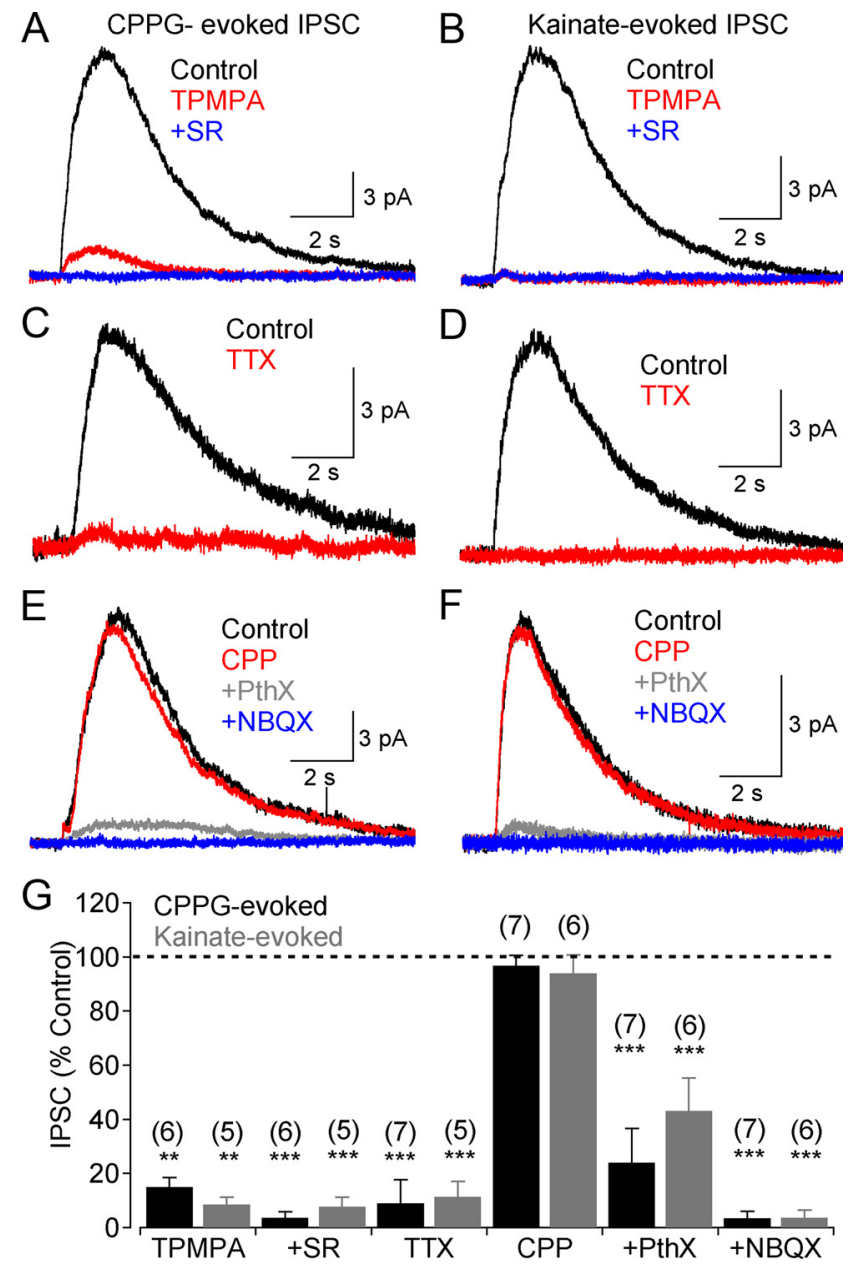

Figure 3. $O N$ and OFF retinal pathways trigger lateral inhibition from GABAergic amacrine cells. $\boldsymbol{A}$, Feedback IPSC s elicited by activation of $0 \mathrm{~N}$ bipolar cell dendrites (puff application of the mGluR antagonist (PPG; $600 \mu \mathrm{M}$ ) in the OPL were strongly reduced by TPMPA (50 $\mu \mathrm{m}$ ) and reduced further by SR95531 (10 $\mu \mathrm{M})$. $\boldsymbol{B}$, Similar results were observed when OFF bipolar cell dendrites were activated by brief puffs of kainate (100 $\mu \mathrm{m}) . \boldsymbol{C}, \boldsymbol{D}$, "ON" (CPPG-evoked) (C) and "OFF" (kainate-evoked) (D) responses were eliminated by TTX (0.5 $\mu \mathrm{m})$. E, CPPG-evoked IPSCS were unaffected by CPP (10 $\mu \mathrm{m})$ but were strongly reduced by $\mathrm{PhTx}(1 \mu \mathrm{M})$ and eliminated by NBQX (25 $\mu \mathrm{m})$. F, Kainate-evoked IPSCs also were insensitive to CPP $(10 \mu \mathrm{m})$, strongly reduced by $\operatorname{PhTx}(1 \mu \mathrm{M})$, and eliminated by NBQX $(25 \mu \mathrm{M})$. G, Summarized drug effects (mean \pm SD) on feedback IPSCs evoked by (PPG (black bars) and kainate (gray bars). All experiments were conducted in the presence of strychnine (3 $\mu \mathrm{M})$, DHT $(50 \mu \mathrm{m})$, and L-AP-4 $(10 \mu \mathrm{M}) .{ }^{* *} p<0.01$; ${ }^{* * *} p<0.001$.
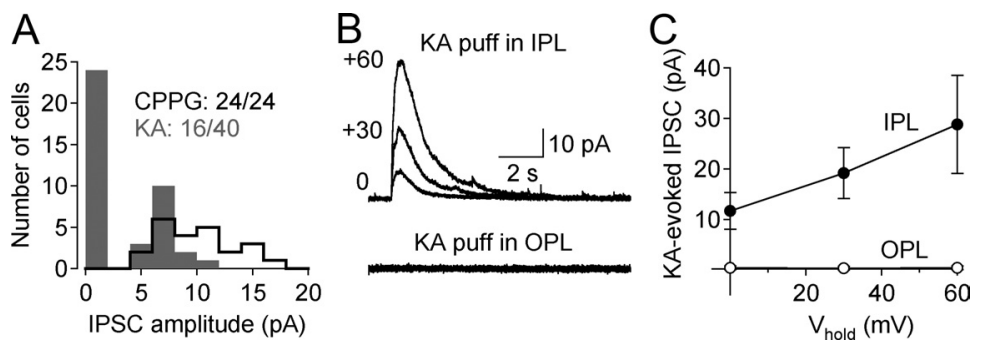

Figure 4. Lateral GABAergic feedback onto RBCs is driven more strongly through the ON pathway. $\boldsymbol{A}$, Amplitude histogram comparing CPPG- and kainate-evoked feedback IPSCS (OPL puff application). $\boldsymbol{B}$, Sometimes kainate failed to evoke IPSCs when puffed directly into the OPL (bottom panel) despite robust responses that could be produced by placing the same puff pipette in the IPL to activate amacrine cell dendrites directly $(n=18)$. C, Summarized data (mean \pm SD) from experiments illustrated in $\boldsymbol{B}$. All experiments were performed in the presence of strychnine ( $3 \mu \mathrm{m})$, DHT (50 $\mu \mathrm{M})$, and 

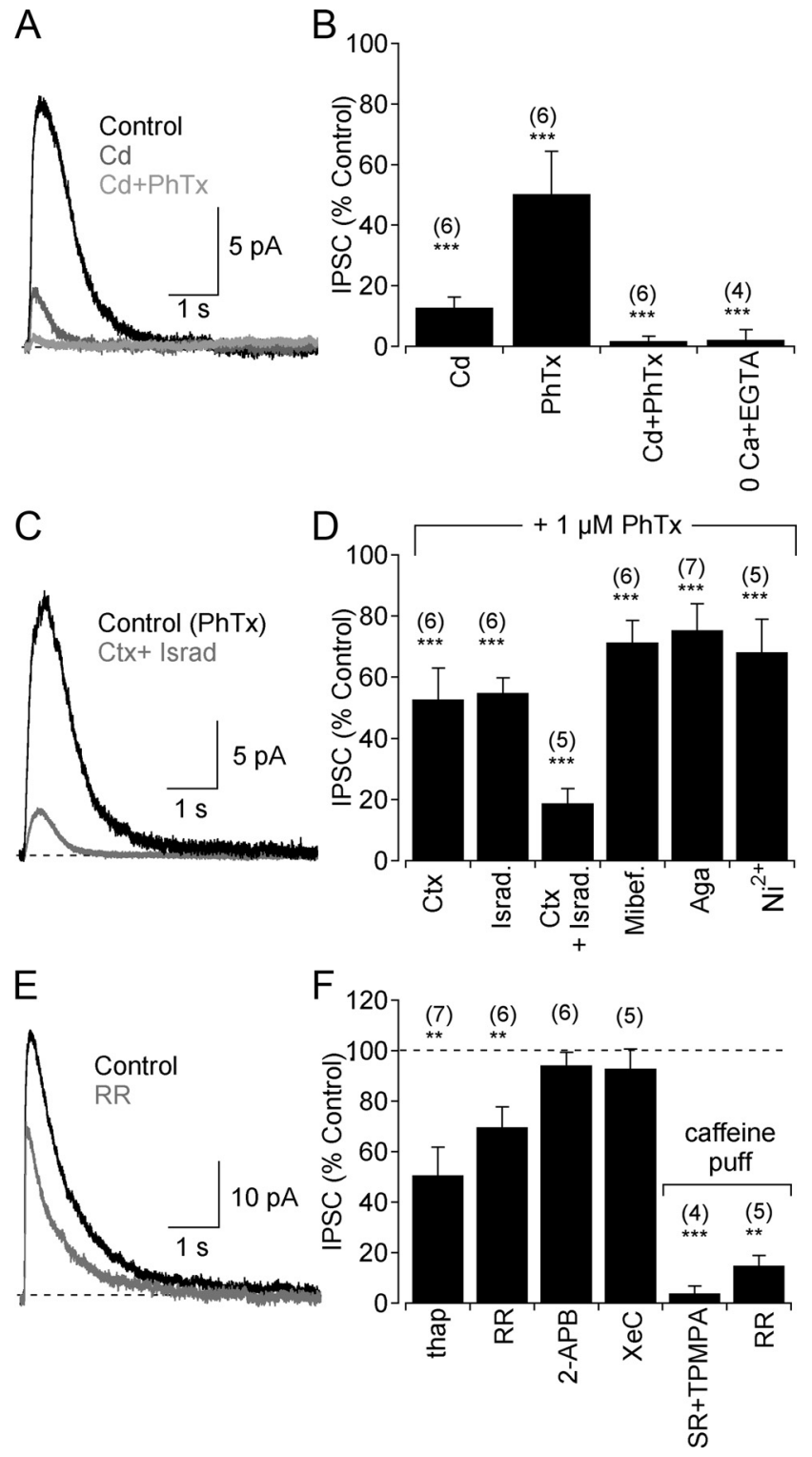

Figure 5. Calcium signals underlying GABA release during lateral feedback. $A$, Glutamateevoked lateral feedback IPSCs were strongly reduced by the nonselective $\mathrm{C}_{v}$ channel blocker, $\mathrm{Cd}^{2+}(200 \mu \mathrm{M})$. The $\mathrm{Cd}^{2+}$-insensitive component of the IPSCS was eliminated by additional inclusion of PhTx $(1 \mu \mathrm{M})$. B , Summarized drug effects (mean \pm SD) on feedback IPSCs. C, Feedback IPSCs evoked in the presence of PhTx (to eliminate $\mathrm{Ca}^{2+}$ influx through AMPARs; control trace) were strongly, but not completely, reduced by coapplication of either $\mathrm{N}$ - or L-type $\mathrm{Ca}_{\mathrm{v}}$ channel antagonists ( $\omega$-conotoxin GVIA, $10 \mathrm{~nm}$, or isradipine, 10 $\mu \mathrm{m}$, respectively). $\boldsymbol{D}$, Summarized effects of $\mathrm{C}_{\mathrm{v}}$ channel blockers (mean $\pm S D$ ) on feedback IPSCs evoked in the presence of $1 \mu \mathrm{m}$ PhTx. E, Feedback IPSCs were reduced by bath application of the RyR antagonist, RR ( $40 \mu \mathrm{M})$, but not the IP $\mathrm{P}_{3}$ antagonist XeC ( $\left.3 \mu \mathrm{M}\right)$. F, Summarized data (mean $\pm S D$ ) showing that RyRs, but not $I P_{3} R s$, contribute to the $\mathrm{Ca}^{2+}$ signaling underlying lateral GABA release. All experiments were performed in the presence of strychnine $(3 \mu \mathrm{m})$ and DHT $(50 \mu \mathrm{M}) .{ }^{* *} p<0.01 ;{ }^{* * *} p<0.001$. Israd, Isradipine; Mibef, mibefradil; Aga, agatoxin IVA; thap, thapsigargin.

and RyR-mediated CICR contribute to intracellular $\mathrm{Ca}^{2+}$ signals that trigger GABA release at lateral feedback synapses onto RBCs.

GABAR activation at reciprocal and lateral feedback synapses Lateral GABAergic feedback inhibition onto RBC terminals is mediated mostly by $\mathrm{GABA}_{\mathrm{C}}$ Rs (Figs. $1 F, 3 A, B$ ). Reciprocal feedback elicited by depolarization of a single $\mathrm{RBC}$ activates primarily $\mathrm{GABA}_{\mathrm{A}}$ Rs (Chávez et al., 2006), but when release from A17s is enhanced a $\mathrm{GABA}_{\mathrm{C}} \mathrm{R}$-mediated component emerges in the reciprocal feedback IPSC (Hartveit, 1999; Singer and Diamond, 2003; Vigh and von Gersdorff, 2005; Chávez et al., 2006). GABA ${ }_{A}$ s and $\mathrm{GABA}_{\mathrm{C}} \mathrm{Rs}$ are clustered separately on RBC axon terminals (Koulen et al., 1998a) and typically only GABA $_{\mathrm{A}}$ Rs are activated by spontaneous GABA release (Frech and Backus, 2004; Eggers and Lukasiewicz, 2006a; Palmer, 2006), suggesting that the two receptor types may be localized to different synapses. One possibility - that $\mathrm{GABA}_{\mathrm{C}}$ Rs are localized to lateral synapses but can be activated by GABA spillover from reciprocal synapses-is countered by anatomical evidence that $\mathrm{GABA}_{\mathrm{C}} \mathrm{Rs}$ are expressed at RBC-A17 contacts (Fletcher et al., 1998). Alternatively, GABA $_{C}$ Rs may be located perisynaptically at either synapse type and become activated only during enhanced release by GABA spillover (Ichinose and Lukasiewicz, 2002; Vigh and von Gersdorff, 2005; Eggers and Lukasiewicz, 2006b; Hull et al., 2006). It is also possible that both receptor types are localized separately at different reciprocal and lateral synapses but that $\mathrm{GABA}_{\mathrm{C}} \mathrm{Rs}$, which bind transmitter much more slowly (Chang and Weiss, 1999), are activated only in response to evoked release of multiple GABA vesicles (supplemental Fig. 1, available at www.jneurosci.org as supplemental material).

To explore these possibilities, we first reexamined the contribution of $\mathrm{GABA}_{\mathrm{C}}$ Rs to reciprocal feedback. In the presence of TTX $(0.5 \mu \mathrm{M})$ and in the absence of DHT, we evoked reciprocal feedback IPSCs by depolarizing a single RBC from -60 to -10 $\mathrm{mV}$. Under these conditions, reciprocal IPSCs are mediated primarily by $\mathrm{GABA}_{\mathrm{A}}$ Rs (Singer and Diamond, 2003; Chávez et al., 2006; Chávez and Diamond, 2008) and exhibited characteristically rapid kinetics (Fig. 6A). As shown previously (Singer and Diamond, 2003), blocking AMPAR desensitization with cyclothiazide (CTZ) $(50 \mu \mathrm{M})$ increased reciprocal GABA release and caused a slower, $\mathrm{GABA}_{\mathrm{C}} \mathrm{R}$-mediated component to emerge in the reciprocal IPSC (Fig. 6A). Although CTZ has been reported to antagonize both $\mathrm{GABA}_{\mathrm{A}} \mathrm{R}$ and $\mathrm{GABA}_{\mathrm{C}} \mathrm{Rs}$ (Deng and Chen, 2003; Xie et al., 2008), in our hands CTZ reduced only slightly $\mathrm{GABA}_{\mathrm{A}} \mathrm{R}$ activation and exerted no effect on $\mathrm{GABA}_{\mathrm{C}} \mathrm{R}$ activation in response to exogenous GABA puffs (supplemental Fig. 2A-D, available at www.jneurosci.org as supplemental material). We also observed that CTZ potentiated GABA release from A17 amacrine cells when stimulated by exogenous glutamate puffs (to $173 \pm 17 \%$ of control response; $p=0.00137$ ) (supplemental Fig. 2, available at www.jneurosci.org as supplemental material) (Grimes et al., 2009). Application of a $\mathrm{GABA}_{\mathrm{A}} \mathrm{R}$ antagonist (SR95531; $10 \mu \mathrm{M}$ ) in the continued presence of CTZ significantly reduced the fast, transient component of the stepevoked feedback response but did not affect the slow, prolonged component (Fig. 6A). Additional inclusion of TPMPA $(50 \mu \mathrm{M})$ abolished this slow component (to $2 \pm 1 \%$ of CTZ current; $p=$ $0.00018 ; n=8$ ) (Fig. $6 \mathrm{~A}$ ), confirming that it was mediated by $\mathrm{GABA}_{\mathrm{C}}$ Rs (Singer and Diamond, 2003; Vigh and von Gersdorff, 2005).

If, during enhanced reciprocal GABA release, $\mathrm{GABA}_{\mathrm{C}} \mathrm{R}$ activation were exclusively extrasynaptic (Vigh and von Gersdorff, 2005), one might expect that blocking GABA transporters, thereby slowing GABA clearance, would enhance activation of extrasynaptic $\mathrm{GABA}_{\mathrm{C}} \mathrm{Rs}$. To test this idea, step-evoked IPSCs were recorded in the presence of CTZ $(50 \mu \mathrm{M})$ (Fig. $6 B)$, and then GABA transporters (GAT-1) were blocked by 1-[2-[[(diphenylmethylene)imino] oxy] ethyl]-1,2,5,6-tetrahydro-3-pyridinecarboxylic acid hydrochloride (NO-711) $(10 \mu \mathrm{M})$. Consistent with previous results, NO-711 applied alone (Chávez et al., 2006; Eggers and Lukasiewicz, 2006b) or in presence of CTZ did not substantially 

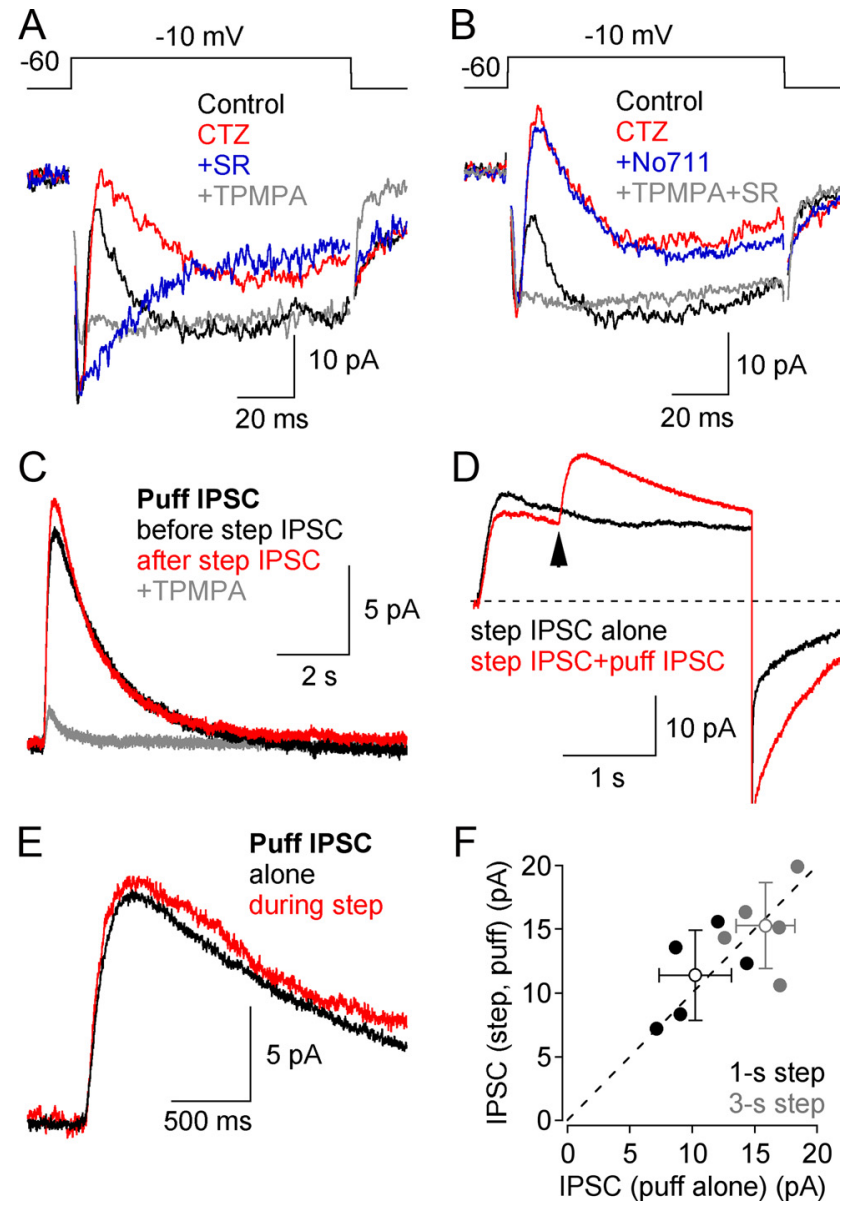

Figure 6. $G A B A_{C} R$ populations activated at lateral and reciprocal feedback synapses are distinct. A, Depolarizing voltage steps ( $50 \mathrm{mV}$ ) elicited reciprocal feedback IPSCs (vIPSCs) (black trace) that were enhanced by blocking AMPAR desensitization with CTZ (50 $\mu$ m; red trace). Additional application of SR95531 (10 $\mu \mathrm{m}$; blue trace) blocked a transient component of the response and revealed a slow $G A B A_{C} R$-mediated component that was eliminated by TPMPA (50 $\mu \mathrm{m}$; gray trace). $\boldsymbol{B}, \mathrm{N} 0-711$ (10 $\mu \mathrm{m}$; blue trace) did not further enhance the $\mathrm{GABA}_{C} \mathrm{R}$-mediated component of the vIPSC. Experiments shown in $\boldsymbol{A}$ and $\boldsymbol{B}$ were done in the presence of TTX and absence of DHT. C, Example from $G A B A_{C} R$ occlusion experiments: $G A B A_{C} R$-mediated nonreciprocal puff-evoked feedback IPSCS (stimulated $\sim 60-80 \mu \mathrm{m}$ from the inhibited RBC) were elicited alone (black) or directly after (red) step-evoked reciprocal activation of GABA $R$ Rs. These experiments were conducted in the presence of CTZ (50 $\mu \mathrm{M})$ and SR95531 (10 $\mu \mathrm{M})$ and in the absence of TTX and DHT. D, vIPSCs showed a slow and sustained GABA ${ }_{C} R$-mediated component IPSC (black trace) that was not occluded by concurrent puff activation of lateral GABAergic feedback synapses (red trace; arrow indicates puff onset). $\boldsymbol{E}$, Comparison of control puff-evoked lateral inhibition from $\left(\right.$ and subtraction of traces in $\boldsymbol{D}$ suggest that distinct $G A B A_{C} R$ populations are involved in reciprocal versus lateral GABAergic feedback. $\boldsymbol{F}$, Summarized data (mean \pm SD)

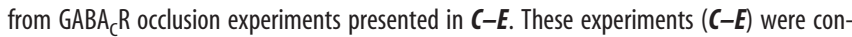
ducted in the absence of TTX and DHT.

increase $\mathrm{GABA}_{\mathrm{A}} \mathrm{R}$-mediated step-evoked IPSCs (to $101 \pm 4 \%$ of CTZ response; $p=0.70741 ; n=6$ ) (Fig. $6 B$ ). Similarly, NO-711 only slightly but insignificantly increased the slow $\mathrm{GABA}_{\mathrm{C}} \mathrm{R}$ mediated step-evoked IPSC (to $112 \pm 14 \%$ of CTZ response; $n=$ $5 ; p=0.06071$ ) (Fig. 6B), suggesting that GAT-1 does not strongly regulate GABAergic transmission at reciprocal synapses. It is unlikely that GABA transporters were saturated under these conditions, because GABA transporters limit the activation of $\mathrm{GABA}_{\mathrm{C}} \mathrm{Rs}$ even when the entire network is activated simultaneously by full-field light stimulation (Eggers and Lukasiewicz, 2006b). Although this result does not exclude spillover between reciprocal and lateral synapses, it suggests that such spillover is not regulated by GAT-1.
If $\mathrm{GABA}_{\mathrm{C}} \mathrm{R}$ activation by GABA spillover mediated significant interaction between reciprocal and lateral synapses, coincident activation of both two pathways could elicit a response that was smaller than the sum of the individual components. This prediction was tested in the presence of $50 \mu \mathrm{M} \mathrm{CTZ}$ and $10 \mu \mathrm{M}$ SR95531, with TTX removed from the ACSF to allow for activation of both reciprocal and nonreciprocal inputs. Lateral synaptic inputs were stimulated with glutamate puffs $\sim 60-80 \mu \mathrm{m}$ away from the recorded RBC (Fig. 6C), and reciprocal inputs were elicited by step depolarization of the RBC (from -60 to $-10 \mathrm{mV}$ for 1 or $3 \mathrm{~s}$ ) (Fig. 6D). Lateral IPSCs were evoked before (Fig. 6C, black trace), during (Fig. $6 D$, arrow), or after the depolarizing voltage step (Fig. 6C, red trace). In all cells tested $(n=10)$ (Fig. 6E, F), neither the amplitude nor the kinetics of lateral $\mathrm{GABA}_{\mathrm{C}} \mathrm{R}$-mediated IPSCs were affected by coincident activation of reciprocal feedback (Fig. 6D-F), suggesting that the two forms of feedback activated distinct pools of $\mathrm{GABA}_{\mathrm{C}}$ Rs.

\section{Discussion}

The present study identifies the cellular and synaptic mechanisms underlying lateral GABAergic feedback onto rat RBC axon terminals and makes comparisons with reciprocal feedback mediated by A17 amacrine cells. Although this electrophysiological study does not directly identify the GABAergic amacrine cell subtypes that mediate nonreciprocal inhibitory inputs, it does provide evidence that distinct sets of amacrine cells mediate reciprocal and lateral GABAergic feedback, highlighting the diversity of physiological mechanisms that underlie inhibitory transmitter release onto RBCs. Specializations among GABAergic amacrine cells might reflect a necessary means to suppress distinct spatial or temporal components of visual signaling in the rod pathway. For example, responses at lateral feedback synapses are mostly $\mathrm{GABA}_{\mathrm{C}} \mathrm{R}$ mediated (Figs. 1-3), suggesting that these inhibitory inputs could be important in shaping tonic glutamate release from RBCs by suppressing regenerative potentials at RBC terminals (Ichinose and Lukasiewicz, 2002; Hull et al., 2006). In contrast, local reciprocal synapses, because of their fast activation kinetics, may play a modulatory role in conferring transience to the visual signal (Euler and Masland, 2000; Dong and Hare, 2003) and/or preventing the rapid depletion of the readily releasable vesicle pool in RBC terminals (Singer and Diamond, 2006). It remains to be determined, however, whether these distinct GABA feedback pathways independently modulate RBC outputs during light-evoked signaling.

In addition to contacting bipolar cell terminals and ganglion cell dendrites, amacrine cells also contact other amacrine cells (Dowling and Boycott, 1966; Dowling and Werblin, 1969; Zhang et al., 2004), primarily via $\mathrm{GABA}_{\mathrm{A}} \mathrm{R}$-mediated synapses (Zhang et al., 1997; Fletcher et al., 1998; Wässle et al., 1998; Eggers and Lukasiewicz, 2010). Although such "serial inhibition" (Zhang et al., 1997) was not evident in our recordings, we cannot exclude the possibility that amacrine-amacrine signaling may have influenced the results of some pharmacological manipulations.

\section{Distinct cell types mediate local versus lateral GABAergic inhibition}

Although some GABAergic amacrine cells can mediate both local and lateral signaling (Cook and McReynolds, 1998) and surround receptive-field organization to ganglion cells (Ichinose and Lukasiewicz, 2005), GABAergic amacrine cells that mediate reciprocal or lateral inhibition to RBCs use unique physiological mechanisms and comprise distinct cell types. At reciprocal synapses, GABA release can occur in the absence of $\mathrm{Ca}_{\mathrm{v}}$ channel 
activation, triggered instead by $\mathrm{Ca}^{2+}$ influx through glutamate receptors (Chávez et al., 2006). Colocalization of excitatory and inhibitory synapses at individual varicosities (Ellias and Stevens, 1980; Nelson and Kolb, 1985) suggests that each A17 reciprocal synapse may operate independently. Consistent with this idea, puff-evoked feedback inhibition from A17 amacrine cells was highly localized to within $\sim 30 \mu \mathrm{m}$ of the inhibited RBC (Fig. 1). In contrast to local reciprocal inhibition from A17, lateral feedback likely plays an important role in spatial processing and thus requires $\mathrm{Na}_{\mathrm{v}}$ channel activation to boost the propagation of membrane depolarization throughout the dendritic arbor. This type of global response/depolarization leads to the activation of $\mathrm{Ca}_{\mathrm{v}}$ channels, predominantly the $\mathrm{L}$ - and $\mathrm{N}$-subtypes, that trigger the release of GABA (Fig. 5). Although $\mathrm{Ca}_{\mathrm{v}}$ channels could be activated by the passive, electrotonic spread of depolarization, the strong sensitivity to TTX (Figs. 1, 3) suggests that the dendritic trees of "lateral" GABAergic amacrine cells possess active conductances that may allow them to generate action potentials (Miller and Dacheux, 1976; Masland, 1988; Bloomfield, 1992; Heflin and Cook, 2007).

\section{Synaptic AMPARs but not NMDARs mediate inputs to GABAergic amacrine cells}

Some amacrine cells express NMDARs (Dixon and Copenhagen, 1992; Boos et al., 1993; Hartveit and Veruki, 1997; Dumitrescu et al., 2006; Chávez and Diamond, 2008), but the range of NMDARpositive cell types is unknown. Here, we find that NMDARs do not contribute to the activation of GABAergic amacrine cells providing lateral feedback to RBCs, similar to previous results at reciprocal GABAergic synapses (Hartveit, 1999; Singer and Diamond, 2003; Chávez et al., 2006). Our pharmacological results suggest possible colocalization of $\mathrm{Ca}^{2+}$-permeable and $\mathrm{Ca}^{2+}$-impermeable AMPAR subtypes on nonreciprocal amacrine cells (Figs. 2, 3), as observed in other retinal neurons (Zhang et al., 1995; Huang and Liang, 2005). Although more thorough examination of glutamate receptor expression by specific amacrine cell subtypes is clearly required, the present results, together with previous physiological work, suggests that GABAergic amacrine cells in the rod pathway express primarily AMPARs (Hartveit, 1999; Singer and Diamond, 2003), whereas glycinergic amacrine cells also express NMDARs (Hartveit and Veruki, 1997; Chávez and Diamond, 2008). The functional consequences of such specificity, which may not extend to all amacrine cell types (Dumitrescu et al., 2006), remains to be determined.

\section{$\mathrm{Ca}^{2+}$ signals underlying nonreciprocal GABA transmitter release}

Typically, presynaptic $\mathrm{Ca}^{2+}$ influx required to trigger transmitter release involves activation of $\mathrm{Ca}_{\mathrm{v}}$ channels (Katz and Miledi, 1967), but in some GABAergic interneurons, $\mathrm{Ca}^{2+}$ influx mediated by NMDARs (Schoppa et al., 1998; Isaacson, 2001; Vigh and von Gersdorff, 2005) or $\mathrm{Ca}^{2+}$-permeable AMPARs (Chávez et al., 2006) can trigger transmitter release. Colocalization of excitatory receptors and GABA release machinery would be expected for this phenomenon to occur, but we find that activation of $\mathrm{Ca}^{2+}$-permeable AMPARs on nonreciprocal GABAergic amacrine cells can trigger some GABA release (Fig. 5), although $\mathrm{N}$ and L-type $\mathrm{Ca}_{\mathrm{v}}$ channels provide the majority of $\mathrm{Ca}^{2+}$ that drives release (Fig. 5). Previous reports indicate that L-type channels often underlie calcium signals and transmitter release at tonically releasing ribbon synapses (Sterling and Matthews, 2005), whereas $\mathrm{N}$-type channels mediate phasic transmitter release at other synapses (Reid et al., 2003). Having multiple $\mathrm{Ca}_{\mathrm{V}}$ channel types control nonreciprocal GABA release may enable specific regulation of synaptic signaling and likely reflects the functional diversity of amacrine cells.

Previous evidence indicates that CICR boosts inhibitory synaptic transmission from amacrine cells (Gleason et al., 1994; Vigh and Lasater, 2003; Warrier et al., 2005; Chávez et al., 2006; Chávez and Diamond, 2008). In "lateral" GABAergic amacrine cells, the enhancement of GABA release onto RBC terminals by CICR is triggered primarily by activation of RyRs but not $\mathrm{IP}_{3}$ Rs (Fig. 5), analogous to our previous results in A17 amacrine cells (Chávez et al., 2006). The two CICR pathways appear to be segregated to different forms of inhibition: in some amacrine cells, $\mathrm{IP}_{3} \mathrm{Rs}$, but not RyRs, are activated by $\mathrm{Ca}^{2+}$ influx through NMDARs (Chávez and Diamond, 2008) and/or intracellular signals from metabotropic glutamate receptors (Warrier et al., 2005; Chávez and Diamond, 2008).

\section{RBCs receive GABAergic feedback inhibition from both $\mathrm{ON}$ and OFF pathways}

The dendritic arbors of wide-field GABAergic amacrine cells extend over great lengths laterally but are typically confined within narrow strata in the IPL and are therefore likely restricted to either the ON or OFF sublaminae (Masland, 1988; MacNeil and Masland, 1998). Here, we find that lateral GABAergic inputs to $\mathrm{RBCs}$ are driven through both the $\mathrm{ON}$ and the OFF pathways (Fig. 3). Notably, however, feedback inputs to RBCs driven by the OFF pathway are smaller in size and less frequently observed than those supplied by the ON pathway (Fig. 4). Although it is possible that these GABAergic inputs to RBCs are mediated by amacrine cells that are activated purely by ON or OFF channels, combinations of $\mathrm{ON}$ and $\mathrm{OFF}$ inputs cannot be ruled out (Werblin and Dowling, 1969; Dacheux and Raviola, 1995; Bloomfield and Völgyi, 2007). Previous work on amacrine cells that respond to both light increments and decrements has shown that these cells can mediate feedforward inhibition to ganglion cells (Cook and Werblin, 1994; Taylor, 1999) or feedback inhibition onto bipolar cells (Shields and Lukasiewicz, 2003) and possess a similar sensitivity to TTX (Miller and Dacheux, 1976; Werblin, 1977; Cook and Werblin, 1994; Miller et al., 2006; Bloomfield and Völgyi, 2007), as observed here (Fig. 3).

\section{$\mathrm{GABA}_{\mathrm{C}}$ Rs are located at both reciprocal and nonreciprocal synaptic inputs}

The apparent segregation of $\mathrm{GABA}_{\mathrm{A}}$ Rs and $\mathrm{GABA}_{\mathrm{C}}$ Rs at the axon terminals of RBCs (Fletcher et al., 1998; Koulen et al., 1998a; Palmer, 2006) is a matter of debate. Previous evidence indicates that $\mathrm{GABA}_{\mathrm{A}}$ Rs mediate most of the reciprocal synaptic inputs (Singer and Diamond, 2003; Chávez et al., 2006), but during increased reciprocal GABA release, $\mathrm{GABA}_{\mathrm{C}} \mathrm{Rs}$ can also be recruited (Hartveit, 1999; Singer and Diamond, 2003; Vigh and von Gersdorff, 2005; Chávez et al., 2006; Eggers and Lukasiewicz, $2006 a, b)$. Here, we find that, although GABA release from nonreciprocal GABAergic amacrine cells activates both $\mathrm{GABA}_{\mathrm{A}} \mathrm{Rs}$ and GABA $_{C}$ Rs (Figs. 1, 3), the majority of the nonreciprocal GABA response $(\geq 90 \%)$ is mediated by $\mathrm{GABA}_{C} \mathrm{Rs}$. One interpretation is that distinct $\mathrm{GABA}_{\mathrm{C}} \mathrm{R}$ populations may be responsible for signaling at reciprocal versus nonreciprocal inputs (Palmer, 2006), but it is also possible that these receptors could be located extrasynaptically (Vigh and von Gersdorff, 2005) and shared by the two types of synapses. Consistent with the former possibilities, we find that the activation $\mathrm{GABA}_{\mathrm{C}}$ Rs during nonreciprocal GABAergic feedback does not occlude activation of $\mathrm{GABA}_{\mathrm{C}} \mathrm{Rs}$ during enhanced reciprocal feedback (Fig. 6), suggesting that the 
responding $\mathrm{GABA}_{\mathrm{C}} \mathrm{Rs}$ comprise distinct, nonoverlapping populations and thus preserving the range of lateral and reciprocal inhibition to RBCs.

\section{References}

Bieda MC, Copenhagen DR (2004) N-type and L-type calcium channels mediate glycinergic synaptic inputs to retinal ganglion cells of tiger salamanders. Vis Neurosci 21:545-550.

Bloomfield SA (1992) Relationship between receptive and dendritic field size of amacrine cells in the rabbit retina. J Neurophysiol 68:711-725.

Bloomfield SA, Völgyi B (2007) Response properties of a unique subtype of wide-field amacrine cell in the rabbit retina. Vis Neurosci 24:459-469.

Bloomfield SA, Xin D (2000) Surround inhibition of mammalian AII amacrine cells is generated in the proximal retina. J Physiol 523:771-783.

Boos R, Schneider H, Wässle H (1993) Voltage- and transmitter-gated currents of all-amacrine cells in a slice preparation of the rat retina. J Neurosci 13:2874-2888.

Chang Y, Weiss DS (1999) Channel opening locks agonist onto the GABA $_{C}$ receptor. Nat Neurosci 2:219-225.

Chávez AE, Diamond JS (2008) Diverse mechanisms underlie glycinergic feedback transmission onto rod bipolar cells in rat retina. J Neurosci 28:7919-7928.

Chávez AE, Singer JH, Diamond JS (2006) Fast neurotransmitter release triggered by $\mathrm{Ca}$ influx through AMPA-type glutamate receptors. Nature 443:705-708.

Cook PB, McReynolds JS (1998) Lateral inhibition in the inner retina is important for spatial tuning of ganglion cells. Nat Neurosci 1:714-719.

Cook PB, Werblin FS (1994) Spike initiation and propagation in wide field transient amacrine cells of the salamander retina. J Neurosci 14:3852-3861.

Cui J, Ma YP, Lipton SA, Pan ZH (2003) Glycine receptors and glycinergic synaptic input at the axon terminals of mammalian retinal rod bipolar cells. J Physiol 553:895-909.

Dacheux RF, Raviola E (1995) Light responses from one type of ON-OFF amacrine cells in the rabbit retina. J Neurophysiol 74:2460-2468.

Deng L, Chen G (2003) Cyclothiazide potently inhibits gamma-aminobutyric acid type A receptors in addition to enhancing glutamate responses. Proc Natl Acad Sci U S A 100:13025-13029.

DeVries SH (2000) Bipolar cells use kainate and AMPA receptors to filter visual information into separate channels. Neuron 28:847-856.

Dixon DB, Copenhagen DR (1992) Two types of glutamate receptors differentially excite amacrine cells in the tiger salamander retina. J Physiol 449:589-606

Dodge FA Jr, Rahamimoff R (1967) Co-operative action a calcium ions in transmitter release at the neuromuscular junction. J Physiol 193:419-432.

Dong CJ, Hare WA (2003) Temporal modulation of scotopic visual signals by A17 amacrine cells in mammalian retina in vivo. J Neurophysiol 89:2159-2166.

Dowling JE, Boycott BB (1966) Organization of the primate retina: electron microscopy. Proc R Soc Lond B Biol Sci 166:80-111.

Dowling JE, Werblin FS (1969) Organization of retina of the mudpuppy, Necturus maculosus. I. Synaptic structure. J Neurophysiol 32:315-338.

Dumitrescu ON, Protti DA, Majumdar S, Zeilhofer HU, Wässle H (2006) Ionotropic glutamate receptors of amacrine cells of the mouse retina. Vis Neurosci 23:79-90.

Eggers ED, Lukasiewicz PD (2006a) $\mathrm{GABA}_{\mathrm{A}}, \mathrm{GABA}_{\mathrm{C}}$ and glycine receptormediated inhibition differentially affects light-evoked signalling from mouse retinal rod bipolar cells. J Physiol 572:215-225.

Eggers ED, Lukasiewicz PD (2006b) Receptor and transmitter release properties set the time course of retinal inhibition. J Neurosci 26:9413-9425.

Eggers ED, Lukasiewicz PD (2010) Interneuron circuits tune inhibition in retinal bipolar cells. J Neurophysiol 103:25-37.

Eggers ED, McCall MA, Lukasiewicz PD (2007) Presynaptic inhibition differentially shapes transmission in distinct circuits in the mouse retina. J Physiol 582:569-582.

Ellias SA, Stevens JK (1980) The dendritic varicosity: a mechanism for electrically isolating the dendrites of cat retinal amacrine cells? Brain Res 196:365-372.

Euler T, Masland RH (2000) Light-evoked responses of bipolar cells in a mammalian retina. J Neurophysiol 83:1817-1829.
Euler T, Schneider H, Wässle H (1996) Glutamate responses of bipolar cells in a slice preparation of the rat retina. J Neurosci 16:2934-2944.

Fletcher EL, Koulen P, Wässle H (1998) $\mathrm{GABA}_{\mathrm{A}}$ and $\mathrm{GABA}_{\mathrm{C}}$ receptors on mammalian rod bipolar cells. J Comp Neurol 396:351-365.

Frech MJ, Backus KH (2004) Characterization of inhibitory postsynaptic currents in rod bipolar cells of the mouse retina. Vis Neurosci 21:645-652.

Gleason E, Borges S, Wilson M (1994) Control of transmitter release from retinal amacrine cells by $\mathrm{Ca}^{2+}$ influx and efflux. Neuron 13:1109-1117.

Grimes WN, Li W, Chávez AE, Diamond JS (2009) BK channels modulate pre- and postsynaptic signaling at reciprocal synapses in retina. Nat Neurosci 12:585-592.

Grünert U, Martin PR (1991) Rod bipolar cells in the macaque monkey retina: immunoreactivity and connectivity. J Neurosci 11:2742-2758.

Habermann CJ, O’Brien BJ, Wässle H, Protti DA (2003) AII amacrine cells express L-type calcium channels at their output synapses. J Neurosci 23:6904-6913.

Hartveit E (1999) Reciprocal synaptic interactions between rod bipolar cells and amacrine cells in the rat retina. J Neurophysiol 81:2923-2936.

Hartveit E, Veruki ML (1997) AII amacrine cells express functional NMDA receptors. Neuroreport 8:1219-1223.

Heflin SJ, Cook PB (2007) Narrow and wide field amacrine cells fire action potentials in response to depolarization and light stimulation. Vis Neurosci 24:197-206.

Huang SY, Liang PJ (2005) $\mathrm{Ca}^{2+}$-permeable and $\mathrm{Ca}^{2+}$-impermeable AMPA receptors coexist on horizontal cells. Neuroreport 16:263-266.

Hull C, Li GL, von Gersdorff H (2006) GABA transporters regulate a standing GABAC receptor-mediated current at a retinal presynaptic terminal. J Neurosci 26:6979-6984.

Ichinose T, Lukasiewicz PD (2002) GABA transporters regulate inhibition in the retina by limiting $\mathrm{GABA}_{\mathrm{C}}$ receptor activation. J Neurosci 22:3285-3292.

Ichinose T, Lukasiewicz PD (2005) Inner and outer retinal pathways both contribute to surround inhibition of salamander ganglion cells. J Physiol 565:517-535.

Ichinose T, Shields CR, Lukasiewicz PD (2005) Sodium channels in transient retinal bipolar cells enhance visual responses in ganglion cells. J Neurosci 25:1856-1865.

Isaacson JS (2001) Mechanisms governing dendritic gamma-aminobutyric acid (GABA) release in the rat olfactory bulb. Proc Natl Acad Sci U S A 98:337-342.

Ivanova E, Müller U, Wässle H (2006) Characterization of the glycinergic input to bipolar cells of the mouse retina. Eur J Neurosci 23:350-364.

Kalbaugh TL, Zhang J, Diamond JS (2009) Coagonist release modulates NMDA receptor subtype contributions at synaptic inputs to retinal ganglion cells. J Neurosci 29:1469-1479.

Kamphuis W, Hendriksen H (1998) Expression patterns of voltagedependent calcium channel alpha 1 subunits (alpha 1A-alpha 1E) mRNA in rat retina. Brain Res Mol Brain Res 55:209-220.

Katz B, Miledi R (1967) Ionic requirements of synaptic transmitter release. Nature 215:651.

Kolb H, Nelson R (1981) Amacrine cells of the cat retina. Vision Res 21:1625-1633.

Koulen P, Brandstätter JH, Enz R, Bormann J, Wässle H (1998a) Synaptic clustering of $\mathrm{GABA}_{\mathrm{C}}$ receptor rho-subunits in the rat retina. Eur J Neurosci 10:115-127.

Koulen P, Malitschek B, Kuhn R, Bettler B, Wässle H, Brandstätter JH (1998b) Presynaptic and postsynaptic localization of $\mathrm{GABA}_{\mathrm{B}}$ receptors in neurons of the rat retina. Eur J Neurosci 10:1446-1456.

Lavoie AM, Tingey JJ, Harrison NL, Pritchett DB, Twyman RE (1997) Activation and deactivation rates of recombinant $\mathrm{GABA}_{\mathrm{A}}$ receptor channels are dependent on alpha-subunit isoform. Biophys J 73:2518-2526.

Lukasiewicz PD, Shields CR (1998) A diversity of GABA receptors in the retina. Semin Cell Dev Biol 9:293-299.

MacNeil MA, Masland RH (1998) Extreme diversity among amacrine cells: implications for function. Neuron 20:971-982.

Masland RH (1988) Amacrine cells. Trends Neurosci 11:405-410.

Miller RF, Dacheux R (1976) Dendritic and somatic spikes in mudpuppy amacrine cells: indentification and TTX sensitivity. Brain Res 104:157-162.

Miller RF, Staff NP, Velte TJ (2006) Form and function of ON-OFF amacrine cells in the amphibian retina. J Neurophysiol 95:3171-3190. 
Nawy S (2004) Desensitization of the mGluR6 transduction current in tiger salamander On bipolar cells. J Physiol 558:137-146.

Nelson R, Kolb H (1985) A17: a broad-field amacrine cell in the rod system of the cat retina. J Neurophysiol 54:592-614.

Palmer MJ (2006) Functional segregation of synaptic $\mathrm{GABA}_{\mathrm{A}}$ and $\mathrm{GABA}_{\mathrm{C}}$ receptors in goldfish bipolar cell terminals. J Physiol 577:45-53.

Raviola E, Dacheux RF (1987) Excitatory dyad synapse in rabbit retina. Proc Natl Acad Sci U S A 84:7324-7328.

Reid CA, Bekkers JM, Clements JD (2003) Presynaptic $\mathrm{Ca}^{2+}$ channels: a functional patchwork. Trends Neurosci 26:683-687.

Schoppa NE, Kinzie JM, Sahara Y, Segerson TP, Westbrook GL (1998) Dendrodendritic inhibition in the olfactory bulb is driven by NMDA receptors. J Neurosci 18:6790-6802.

Shields CR, Lukasiewicz PD (2003) Spike-dependent GABA inputs to bipolar cell axon terminals contribute to lateral inhibition of retinal ganglion cells. J Neurophysiol 89:2449-2458.

Singer JH, Diamond JS (2003) Sustained $\mathrm{Ca}^{2+}$ entry elicits transient postsynaptic currents at a retinal ribbon synapse. J Neurosci 23:10923-10933.

Singer JH, Diamond JS (2006) Vesicle depletion and synaptic depression at a mammalian ribbon synapse. J Neurophysiol 95:3191-3198.

Sterling P, Lampson LA (1986) Molecular specificity of defined types of amacrine synapse in cat retina. J Neurosci 6:1314-1324.

Sterling P, Matthews G (2005) Structure and function of ribbon synapses. Trends Neurosci 28:20-29.

Taylor WR (1999) TTX attenuates surround inhibition in rabbit retinal ganglion cells. Vis Neurosci 16:285-290.

Veruki ML, Mørkve SH, Hartveit E (2006) Activation of a presynaptic glutamate transporter regulates synaptic transmission through electrical signaling. Nat Neurosci 9:1388-1396.

Vigh J, Lasater EM (2003) Intracellular calcium release resulting from mGluR1 receptor activation modulates $\mathrm{GABA}_{\mathrm{A}}$ currents in wide-field retinal amacrine cells: a study with caffeine. Eur J Neurosci 17:2237-2248.
Vigh J, Lasater EM (2004) L-type calcium channels mediate transmitter release in isolated, wide-field retinal amacrine cells. Vis Neurosci 21:129-134.

Vigh J, von Gersdorff H (2005) Prolonged reciprocal signaling via NMDA and GABA receptors at retinal ribbon synapse. J Neurosci 25:1141211423.

Völgyi B, Xin D, Bloomfield SA (2002) Feedback inhibition in the inner plexiform layer underlies the surround-mediated responses of AII amacrine cells in the mammalian retina. J Physiol 539:603-614.

Warrier A, Borges S, Dalcino D, Walters C, Wilson M (2005) Calcium from internal stores triggers GABA release from retinal amacrine cells. J Neurophysiol 94:4196-4208.

Wässle H, Koulen P, Brandstätter JH, Fletcher EL, Becker CM (1998) Glycine and GABA receptors in the mammalian retina. Vision Res 38:1411-1430.

Werblin FS (1977) Regenerative amacrine cell depolarization and formation of on-off ganglion cell response. J Physiol 264:767-785.

Werblin FS, Dowling JE (1969) Organization of the retina of the mudpuppy, Necturus maculosus. II. Intracellular recording. J Neurophysiol 32:339-355.

Xie A, Song X, Ripps H, Qian H (2008) Cyclothiazide: a subunit-specific inhibitor of GABAC receptors. J Physiol 586:2743-2752.

Xu HP, Zhao JW, Yang XL (2002) Expression of voltage-dependent calcium channel subunits in the rat retina. Neurosci Lett 329:297-300.

Zhang D, Sucher NJ, Lipton SA (1995) Co-expression of AMPA/kainate receptor-operated channels with high and low $\mathrm{Ca}^{2+}$ permeability in single rat retinal ganglion cells. Neuroscience 67:177-188.

Zhang J, Jung CS, Slaughter MM (1997) Serial inhibitory synapses in retina. Vis Neurosci 14:553-563.

Zhang J, Wang HH, Yang CY (2004) Synaptic organization of GABAergic amacrine cells in the salamander retina. Vis Neurosci 21:817-825. 